Acta Poetica $26(1-2)$

PRIMAVERA-OTOÑO

\title{
Los caminos de la memoria: oralidad y textualidad en la construcción social del tiempo
}

\begin{abstract}
Luis Díaz G. Viana
¿Por qué la recuperación de la memoria colectiva — por dolorosa que aquélla pueda resultar - ha pasado a ser un asunto socialmente tan importante en algunos países durante los últimos años? ¿Se está convirtiendo la memoria en un auxiliar o en un sustituto de la historia peor conocida? Parecería que la oralidad — con la que implícitamente se suele relacionar a tal restitución de la memoria- adquiriera en este contexto, respecto a la textualidad, una suerte de fiabilidad renovada o renovadora. El autor pone en conexión, a lo largo de este trabajo, la oralidad y la escritura con las diferentes maneras de recordar y — más en concreto- con la distinción, que ya establecieron ciertos filósofos griegos, entre memoria y recuerdo. Desde este enfoque, la llamada literatura oral - hoy menos "pura" que nunca en virtud de las nuevas formas de comunicación tecnificada en que lo oral y lo escrito se difuminan - emerge con inédita actualidad y especial relevancia en la reconstrucción social del tiempo. Pues quizá busquemos — sin saberlo— en la memoria transhistórica que la oralidad propicia, enlazando los tiempos, una continuidad de la experiencia que creíamos haber perdido. Y, de este modo, la hipotética curación por la memoria que los diversos intentos de recuperación de ésta parecen asumir como posible.
\end{abstract}

Why has the recovery of collective memory, no matter how painful, become such an important issue in some countries for the last few years? Is memory turning into an accessory, or a substitute, for the lesser known history? It would seem that oral narratives, with which this exercise of re-connecting with the past has been implicitly related, acquire in the current context a sort of renovated or renewing reliability with respect to the written texts. In this essay the author relates both orality and the written texts with the different ways of remembering and with the distinction between memory and recollection already made by Greek philosophers. From this perspective, oral literature — nowadays less "pure" than ever, since the new forms of technological communication blend the oral and the written- emerges with unprecedented strength and with special relevance in the social reconstruction of time. Perhaps we search in orality's transhistorical memory a continuity of experience we thought we had lost. 

Acta Poetica 26 (1-2)

PRIMAVERA-OTOÑO

2005

Luis Díaz G. Viana

Departamento de Antropología de España y América del CSIC

\section{Los caminos de la memoria: oralidad y textualidad en la construcción social del tiempo}

Es una dama misteriosa la memoria

Manuel Rivas, En salvaje compañía

1. Escritura y oralidad: una vieja oposición entre las distintas formas de recordar

Platón señalaba en su diálogo de Fedro, mediante palabras puestas en boca de Sócrates, que la escritura - como la pintura - presenta ante nosotros una copia de la realidad y no el original:

En efecto, sus vástagos están ante nosotros como si tuvieran vida; pero, si se les pregunta algo, responden con el más altivo de los silencios. Lo mismo pasa con las palabras (Lledó 2000, 275, D4-13).

En el diálogo de Sócrates con Fedro la escritura no aparece siquiera como un "fármaco de la memoria", sino como "un simple recordatorio". Y así se lo expresa el rey Thamus al dios Teuth - tras inventar éste las letras - en la fábula pretendidamente egipcia que Sócrates cuenta a su joven amigo sobre el 
origen de la escritura. Lo que puede ser entendido como un viejo rechazo de los hombres más sabios a los adelantos tecnológicos. Paradójicamente, hoy sabemos de Sócrates y de lo que pensaba sobre la escritura gracias a que Platón, al parecer, no cumplió a "rajatabla" — sería impropio, dado el caso, decir "al pie de la letra" - unas enseñanzas, en apariencia, tan retrógradas. Pero también es cierto que, por lo mismo que apuntaba Sócrates, ya nunca sabremos — a ciencia cierta— qué era exactamente lo que él decía y lo que se debe a Platón cuando lo escribió.

Este pasaje ha sido recordado y discutido muchas veces por varios autores, pero Carlo Ginzburg volvió a traerlo —recientemente - a colación a propósito de la "impresión" grabada en la memoria por lo que percibimos hoy no "realmente", sino a través de las "nuevas tecnologías", aunque —como en el caso de lo ocurrido en el $11 \mathrm{~S}$ - fuera visto, más o menos, "en tiempo real":

El lenguaje que empleamos hoy al hablar de la memoria se basa en general en las mismas metáforas utilizadas por Platón y Aristóteles. Decimos, por ejemplo, que los acontecimientos del 11 de septiembre de 2001 dejaron una marca imborrable en la memoria de cuantos los presenciaron. Y cuando decimos 'presenciar', damos un nuevo significado a una palabra que durante mucho tiempo se refería exclusivamente a la acción directa, o autopsia, como lo llamaban los médicos e historiadores en la antigua Grecia. Porque la gran mayoría de quienes, en todo el mundo, presenciaron el ataque contra las torres gemelas, lo vieron por la pantalla de televisión: el medio proporcionó un acceso universal simultáneo a un acontecimiento sin precedentes verdaderamente global. (Ginzburg 2004, 35)

Este acto de "presenciar" lo que se ve, si bien no se esté allí donde sucede, al mismo tiempo o con levísima demora, introduce un elemento de comunicación nuevo que tiene que ver 
no sólo con la escritura, sino también con la oralidad y, en el sentido más amplio del término, con la "lectura".

Parecería que hay diferentes tipos de memoria o que caben diferentes formas de recordar dentro de lo que solemos identificar como memoria. La memoria, tanto individual como colectiva, a menudo adquiere la forma de literatura, ya se produzca la transmisión de lo literario de manera escrita u oral, combinándose con frecuencia en la práctica ambas vías. Walter Benjamin indagó sobre esa relación entre memoria y literatura: de Proust a Baudelaire reconoce Benjamin en el escritor, en el poeta y, por ello, en toda literatura la capacidad no sólo de perpetuar los recuerdos, sino también de profundizar en la memoria; en las memorias, la voluntaria e involuntaria, la consciente e inconsciente. En el reconocimiento de una memoria involuntaria e inconsciente como verdadera memoria o - incluso- como la memoria más verdadera, jugó un papel importante la obra de Freud, al que Benjamin alude por eso inevitablemente:

La proposición fundamental de Freud [...] formula la suposición de que 'la conciencia surge en el lugar de la huella de un recuerdo' [...] Los residuos del recuerdo 'son a menudo más fuertes y más firmes, cuando el proceso que los deja atrás jamás llega a ser consciente. Traducido a la manera de hablar de Proust: sólo puede ser componente de la memoria involuntaria lo que no ha sido 'vivido' explícita y conscientemente, lo que no le ha ocurrido al sujeto como 'vivencia' [...] Según Freud, la conciencia en cuanto tal no acogería ninguna huella de la memoria. (Benjamin 1993, 129)

Freud, en efecto, reconoció implícitamente en varios de sus trabajos el valor de indagación que el arte -y más en concreto la literatura - tenía para desentrañar las relaciones de lo consciente y lo inconsciente en la memoria humana. Un tributo a ese reconocimiento son los estudios que dedicó a varios 
creadores, de Leonardo da Vinci a Goethe, pasando por Dostoievski o Jensen. En un pasaje de su trabajo titulado "Un recuerdo infantil de Leonardo da Vinci" establece un interesante paralelismo entre cómo los individuos reconstruyen sus recuerdos de infancia con la manera en que los pueblos reconstruyen su historia peor conocida:

Los recuerdos infantiles de los hombres no tienen a veces otro origen. En lugar de reproducirse a partir del momento en que quedan impresos, como sucede en los recuerdos conscientes de la edad adulta, son evocados al cabo de mucho tiempo, cuando la infancia ha pasado ya, y aparecen entonces deformados, falseados, y puestos al servicio de tendencias ulteriores, de manera que no resultan estrictamente diferenciables de las fantasías. Como mejor podemos explicarnos su naturaleza es pensando en el nacimiento de la crónica histórica en los pueblos antiguos. Mientras el pueblo fue pequeño y débil no pensó en escribir su historia y se limitó a labrar su suelo, a defender su existencia contra sus vecinos, a ampliar sus dominios y a enriquecerse. Fue esta una época heroica y sin historia. Pero a ella sucedió otra en la que el pueblo adquirió ya conciencia de sí mismo, se sintió rico y poderoso y experimentó la necesidad de averiguar de dónde procedía y cómo había llegado a su estado actual. La Historia, que había comenzado por anotar simplemente los sucesos de la actualidad, dirigió entonces su mirada hacia el pasado, reunió tradiciones y leyendas, interpretó las supervivencias del pretérito en los usos y costumbres y creó así una historia del pasado prehistórico. Pero esta prehistoria había de constituir, sin remedio, más bien una expresión de las opiniones y deseos contemporáneos que una imagen del pasado, pues gran parte de éste había caído en el olvido, otra se conservaba deformada, muchas supervivencias se interpretaban equivocadamente bajo la influencia de las circunstancias del momento y, sobre todo, no se escribía la historia por motivos de ilustración objetiva, sino con el propósito de actuar sobre los contemporáneos. El recuerdo consciente que los hombres conservan de los sucesos 
de su madurez puede compararse a esta redacción de la Historia y sus recuerdos infantiles corresponden, tanto por su origen como por su autenticidad, a la historia de la época primitiva de un pueblo, historia muy posterior a los hechos y tendenciosamente rectificada. (Freud 1973, 25-26)

Con todos los matices que, hoy, cabría añadir a este texto, el comentario puede seguir siendo —esencialmente- válido. Quizá casi toda la historia rectifique "tendenciosamente" el pasado. Y la memoria hecha de testimonios directos también. Pero nos vale esa precisión que Freud parece apuntar que el recuerdo no consciente puede ser tan importante o más que el otro, aunque esté forzosamente actualizado. Y la apreciación de que el recuerdo siempre se actualiza. La historia lo hace igualmente, pues aunque se base en los hechos recogidos por escrito en una época dada no por ello resulta - la mayoría de las veces-, en su selección de textos y en su interpretación inevitable de los mismos, menos actualizadora y "tendenciosa"; o, si se prefiere, proclive al "presentismo". Por último, da la impresión de que Freud concede más credibilidad histórica a lo escrito que a lo conservado oralmente o "por costumbre". Lo que también puede ser muy discutible y a ello volveremos después.

\section{La memoria y el recuerdo: una distinción que viene de lejos}

Retomemos ahora la distinción entre el recuerdo y la memoria que en Freud parecen corresponderse respectivamente con la historia y con la costumbre o, si se prefiere, con la "tradición". ¿Tendría que ver ésta con la memoria involuntaria o inconsciente más que con el recuerdo de "lo vivido"? El propio Benjamin escribiría en otro lugar, en este sentido, sobre todo lo que no podemos o queremos recordar, que quizá forme también parte de la memoria aquello que se oculta tras la apariencia del olvido: 
Jamás podremos rescatar del todo lo que olvidamos. Quizá esté bien así. El choque que produciría recuperarlo sería tan destructor que al instante deberíamos dejar de comprender nuestra nostalgia. De otra manera la comprendemos, y tanto mejor, cuanto más profundo yace en nosotros lo olvidado. (Benjamin $1982,76)$

Freud intenta en su aplicación del psicoanálisis al arte o, mejor, a la vida y a la infancia de los artistas (como en los casos de Leonardo y Goethe), explicar por qué ciertos creadores reconstruyeron determinados recuerdos infantiles que, en rigor, por la edad a que se refieren, probablemente no serían fáciles de recordar en la realidad. Y dice en su breve trabajo "Poesía y verdad" refiriéndose a un lejano recuerdo de Goethe:

No es indiferente ni insignificante qué detalle de la vida infantil se haya sustraído al olvido general de la infancia. Más bien hemos de sospechar que lo que se ha conservado en la memoria es también lo más importante de aquel estadio de la vida, bien porque ya en su tiempo entrañara tal importancia, bien porque la haya adquirido después, bajo la influencia de acontecimientos posteriores. (Freud 1973, 203)

Pero quizá una distinción no menos importante entre los tipos de memoria o entre memoria y recuerdo, si queremos continuar con la dicotomía que ya apuntaban los filósofos griegos, sea la que viene dada por las acepciones que tienen en la actualidad en nuestra propia lengua y también en otras (como el inglés) estos términos, pues parece que aquella vieja diferenciación linguiística y conceptual continúa existiendo — de alguna manera - en el momento actual: así, de una parte, "recuerdo" hace referencia — según algunos diccionarios - a "la imagen o complejo de imágenes a través de las cuales se reiteran en nuestra mente personajes, cosas, situaciones o escenas que hemos percibido con anterioridad, con alusión al tiempo de su percep- 
ción" (Vox 1994); de otro lado, la "memoria" es definida en ellos como la "facultad (o potencia) del alma por la cual reproducimos mentalmente objetos ya conocidos, refiriéndose al pasado de nuestra vida" (Vox y RAE). Curiosamente, en otras acepciones de los mismos términos, "memoria" se identifica con "disertación o recordatorio escrito" (Vox) y "estudio o disertación escrita sobre alguna materia" (RAE). Y resulta interesante esta acepción cuyo uso es frecuente en el español actual $-\mathrm{y}$ todos hemos utilizado alguna vez- porque en ella se relaciona a la "memoria" con lo escrito, justamente al revés de lo que parece ocurrir en el empleo de memoria como testimonio oral y directo; un uso éste que parece contraponerse en tiempos recientes a la historia entendida convencionalmente que se ha basado, por lo general, en fuentes textuales. Escribe, así, Ginzburg que, desde tal perspectiva, "la memoria parece hoy más apropiada que la historia para ocuparse de la demanda de una retribución simbólica" (Ginzburg 2004, 37).

Considero, en todo caso, ilustrativas también esas primeras acepciones de la memoria como facultad o capacidad de recordar y del recuerdo como imagen del pasado, porque guardan un cierto paralelismo con determinadas dimensiones que concedemos a otros términos relacionados con la cultura. Por ejemplo, cuando hablamos de la cultura en un sentido patrimonial —el que siempre tuvo la Gran Cultura-, de la Gran Tradición (Redfield 1960) o "cultura de los cultos", nos estamos refiriendo - generalmente- a imágenes o recuerdos de lo que la humanidad fue. Sin embargo, cuando nos referimos a la cultura en un sentido antropológico deberíamos saber que estamos aludiendo - sobre todo - a la capacidad o facultad humana de producir y transmitir conocimientos. La cultura es memoria. El hombre es un animal hecho de memoria. Y con el término de "cultura popular" apuntamos especialmente a esa capacidad de crear y transmitir cualquier clase de cultura que todo humano tiene. El hombre es cultura y la cultura es memoria más que 
recuerdo cierto o consciente. De hecho, los casos históricos de niños salvajes que conocemos vinieron a demostrar que, aunque el ser humano - por serlo- tenga inherentemente ambas capacidades (la de recordar y hacer cultura), si no las desarrolla colectivamente no adquiere por sí solo la condición humana:

El problema de los niños salvajes, niños que vuelven a la vida en sociedad tras sobrevivir en la naturaleza en completa soledad y cuyos progresos en las habilidades lingüísticas son significativamente escasos (retrocediendo a estados evolutivos lejanísimos) se explica — según Chomsky - por la existencia de un período crítico en el aprendizaje, como ocurre con la visión humana o en determinadas facultades de algunos animales. (Gómez Soto 1999, 59)

Sería este salvaje solitario un animal incompleto si no llenara con cultura el espacio de su mente que tiene programado para ello. Sin embargo, no somos generalmente conscientes tampoco de cuándo realizamos esos aprendizajes decisivos, del andar al hablar, del hablar al leer y del leer al escribir. Benjamin en su escrito titulado significativamente "Juego de letras" lo resume así:

La nostalgia que despierta en mí (el juego de letras) demuestra cuán estrechamente estaba ligado a mi infancia [...]. La mano (con la que colocaba esas letras de niño) puede soñar el manejo, pero nunca podrá despertar para realizarlo realmente. Así, más de uno soñará en cómo aprendió a andar. Pero no le sirve de nada. Ahora sabe andar, pero nunca jamás volverá a aprenderlo. (Benjamin 1982, 77)

Según la enseñanza socrática, que recoge y no sabemos hasta qué punto rehace Platón en su Fedro, "el verdadero conocimiento es un recuerdo de realidad intemporal" (Ginzburg 2004, 30), lo que parece coincidir con las posiciones de Freud y Benjamin al respecto, por distantes que puedan estar estos autores en otros 
asuntos. Aunque — tal como señala Ginzburg — hay pasajes de Platón en que la distinción entre memoria (mneme) y recuerdo (anamnesis) parece flaquear o al menos transmitirse "a través de un vocabulario amplio y flexible", resulta claro que la distinción —e incluso oposición — entre memoria y recuerdo "tenía un papel central en el pensamiento de Platón” (Ginzburg 2004, 34).

Aristóteles, en su obra De la memoria y el recuerdo, habría dado —en la opinión de Ginzburg — un cierto giro antiplatónico a esta distinción, pues para este otro sabio heleno "no era el recuerdo ni la recuperación ni la adquisición de la memoria, ya que cuando uno por primera vez aprende o recibe una impresión sensible, no recupera ninguna memoria", a pesar de que "en el caso de la memoria (mneme) la actitud de Aristóteles hacia Platón era más compleja” (Ginzburg 2004, 34). Para Aristóteles, el recuerdo "implica la memoria y va acompañado de memoria" (Ginzburg 2004, 35); sin embargo, para Sócrates y Platón la memoria lo precede y sobrevive, es algo más que recordar, es saber antes de ser conscientes de lo que sabemos.

Hoy cabría decir — basándose en un lenguaje actualizado por las innovaciones tecnológicas - que, si bien ambos filósofos nunca se lo habrían imaginado, existe un cierto paralelismo entre la distinción platónica de memoria y recuerdo y la que podemos establecer "entre la información y la recuperación de información de una base de datos" (Ginzburg 2004, 33). El mismo Ginzburg se pregunta si tiene o no sentido esa comparación. Quizás hace —en cualquier caso- más entendible para nosotros tal dicotomía, sobre todo si identificamos a la memoria con la memoria informática o los programas de los ordenadores que la activan y al recuerdo con el acto ejecutor de recuperar datos desde ella. Incluso así podemos comprender mejor la desconfianza de Sócrates y Platón ante la innovación tecnológica de su tiempo, la escritura, que al producirse a través de "carácteres (sic) ajenos [...] conducía a la atrofia de la memoria" (Ginzburg 2004, 35). Parecido recelo al que hoy es compartido 
por muchas personas que, aunque asumen que los medios tecnológicos sirven para acumular más información y transmitirla con inmediatez, también creen que, en todo ese proceso, se pierde la experiencia de un verdadero conocimiento y la auténtica comunicación:

La palabra escrita imita al original, es decir, explica Sócrates, la "que se escribe con ciencia en el alma del que aprende". "¿Te refieres a ese discurso lleno de vida y de alma, que tiene el que sabe y del que el escrito se podría justamente decir que es el reflejo (eidolon)" se interroga Fedro. "Sin duda", le responde Sócrates. Es decir, el original sólo puede surgir del intercambio dialéctico ilustrado en los diálogos de Platón: una forma de interacción intelectual desconocida para las culturas orales tradicionales. (Ginzburg 2004, 32)

Pero ¿realmente era esta dialéctica socrática ajena a la oralidad preexistente? No parece que quienes la practicaban fueran muy conscientes de ello: Sócrates se vale, para mostrar su suspicacia ante la escritura, de una leyenda de dudoso pedigrí egipcio sobre la cual el propio Fedro le dice: "Qué bien se te da, Sócrates, hacer discursos de Egipto, o de cualquier otro país que se te antoje" (Ginzburg 2004, 30). Exactamente igual que los mitos orales que siempre se han contado y que, según señalaba Freud, se siguen contando — como los recuerdos más remotos de la infancia - por lo que valen o pueden servir, hoy, para nosotros. Por otra parte, lo que parece reivindicar la enseñanza socrática, más allá del aparente rechazo de la escritura — que consignaría mediante "carácteres [sic] ajenos" la memoria-, es la interacción de emisor y receptor, el valor de lo que uno cuenta a otro y, en definitiva, la importancia del diálogo y la conversación. Porque como señalará Zumthor:

El oyente contribuye así a la producción de la obra en la performance. Es el oyente-autor no menos autor que el ejecutante. 
De ahí la especifidad del fenómeno de la recepción en la poesía oral. (Zumthor 1983, 234)

No deja de ser paradójico, y además revelador, que todo el diálogo de Sócrates y Fedro surja y se estructure en torno a un texto del retórico Lisias sobre el amor que ambos comentan en su paseo a la sombra de los árboles fuera de los muros de Atenas. Lejos de negar lo que Sócrates dice y defiende, esta circunstancia aclara el sentido de sus pensamientos. ¿Cómo? Ahora lo veremos. No importa tanto el origen del mensaje si no cómo se actúa sobre él. Tampoco si algo surgió oral o no, si no que se pueda discutir entre dos, recrearlo socialmente en un mismo espacio y tiempo, no en el espacio-tiempo diferido impuesto por la escritura. Sócrates y Fedro, en un contexto campestre - extramuros de la ciudad - que parece remitir a épocas pasadas o intemporales, hacen presente a Lisias y de ahí se establece un nuevo diálogo aclarativo. No se trata de negar rotundamente la escritura, sino de incorporarla a una forma y contexto de razonamiento que para Sócrates y sus discípulos seguía siendo esencial.

\section{Inéditas posibilidades de "presenciar" lo vivido: nuevas y viejas formas de oralidad y textualidad}

Ginzburg recoge la opinión de Goody en La domesticación del pensamiento salvaje de que escribir permite hablar libremente de nuestros pensamientos y de que ese prolongado monólogo —difícil de mantener oralmente - se ha ido perfeccionando con "instrumentos de escritura que permiten una grabación rápida" (Ginzburg 2004, 31). Y precisa que, aunque Goody no se refiere al ordenador por el momento aún temprano en que escribió esta obra (1977), "todos los instrumentos de la lista citada por él (la taquigrafía, la máquina de escribir eléctrica) implican 
diferencias de grado, no de tipo" (Ginzburg 2004, 32). De hecho, el ordenador y la comunicación por internet han generado inéditas formas de escritura e interacción, tan efímeras como la palabra oral en la mayoría de los casos y casi tan inmediatas como ella. Quizá por eso internet ha favorecido también la circulación de cuentos, chistes y leyendas en los últimos tiempos. Siendo, además, éste el medio favorito para transmitir cultura popular por parte de los más jóvenes. Esta forma de transmisión difumina en cierto modo la línea entre oralidad y escritura que parecía infranqueable, pues incluso podría hablarse, hoy, de un "boca a boca cibernáutico" que participa de caracteres que hasta ahora se creía exclusivamente reservados a la oralidad. Y de que, por ello, "los resortes que hacen posible el folklore siguen funcionando plenamente en nuestro mundo" (Díaz 2003, 85).

En efecto, en la escritura siempre importó quién escribía, quién certificaba lo escrito; se escribía — de hecho- en un momento distinto a aquel en que el lector decodificaba lo cifrado, y en un espacio distinto. Todo esto ha cambiado. Quien lo escribe no importa ahora, como mucho quien nos lo envía, el tiempo puede ser casi el mismo - especialmente si se trata de un SMS - , la interacción inmediata entre emisor y receptor - además- es posible aunque se utilice la escritura (o algo parecido a ella) como medio de comunicación. El espacio — por último- aunque parezca también diferente, uno en que el emisor escribe y otro en el que el receptor lo lee -que pueden incluso encontrarse en países y continentes distintos- es, en el fondo, el mismo: un nuevo espacio virtual. Se trataría de una especie de "autógrafo oral" internáutico, no igual pero tampoco tan distante de aquellos oral autograph texts a los que se refiriera Lord y que habrían servido para consignar los primeros poemas épicos de la humanidad (Lord 1960, 149). Todo ello aproxima, en cualquier caso, estas formas de transmisión de los mensajes a lo que se entiende por oralidad. Los esfuerzos por 
definir a ésta casi siempre se han centrado más en el emisor que en el receptor, ya desde los tiempos en que los griegos polemizaban sobre lo oral y lo escrito; y mucho menos en el receptor. Las nuevas formas de oralidad y textualidad nos revelan - aún con mayor claridad- que, sin embargo, lo que más puede haber diferenciado a ambas formas de comunicación estriba en el tipo de relación entre emisor y receptor y, sobre todo, en la actitud de éste ante lo transmitido. No se trata tan sólo de que en la comunicación literaria establecida desde la oralidad el autor sea "legión" — como ya señaló Menéndez Pidal—, sino de que el receptor, el "lector" en un sentido amplio y genérico también lo es; porque — seguía diciendo el más ilustre estudioso de nuestro romancero- - "el pueblo, la colectividad, poetiza realmente" (Menéndez Pidal 1973, 396). Un "lectorlegión" que, en cierto modo, resulta coautor del mensaje o que puede ser el próximo autor-transmisor de lo comunicado. La estructura de tal narrativa será — por lo tanto- "abierta", pero no únicamente porque el relato no esté cerrado, terminado; también porque no es de nadie o es de todos, porque cualquiera puede participar en su transformación.

La lectura individualizada — también hubo y hay, a veces, una lectura colectiva que participa de lo oral- determina que dos soledades pueden encontrarse en el acto de leer. Y ello constituye, sí, como señalaba Goody, un acto de libertad pues consiste — básicamente - en una elección individual. El escritor toma decisiones, generalmente, solo y el lector elige por sí mismo continuar o no con la lectura e incluso "saltarse" unas partes o volver a otras. La interacción está, así, muy condicionada por el momento en que el lector decide leer y reinterpretar lo leído y el contexto de individualidad en que lo hace. Las otras formas de "lectura" — propias de la oralidad— de que hablamos, entre autores y lectores que son los mismos o pueden intercambiar sus roles, hacen de la colectividad el emisor y el receptor al tiempo. Este lector es —asimismo — un "lector-le- 
gión", no un lector individual. Con la terminología actual diríamos que se trata de una "lectura interactiva", como sin duda era la que se hacía de los pliegos de cordel en los "patios de vecindad" hace más de un siglo (Díaz 2001, 20). Pero no sólo eso: lo que se transmite colectivamente es, en muchas ocasiones, ya conocido por esa misma colectividad; e incuso puede responder a distintos tiempos de memoria. Resulta significativo, en este sentido, lo que los llamados informantes de la literatura considerada como tradicional dicen off the record, a propósito de lo que cantan o recitan, y los recopiladores no suelen incluir en ningún lugar de sus publicaciones. Así, la informante de un romance muy conocido, el denominado como de "Don Bueso y su hermana cautiva", me cantó una versión —en cierta ocasión — que constaba de dos partes bien diferenciadas. La primera era la actualización del viejo tema al periodo finisecular de las guerras de África, y consistía en el recitado de unas coplas al estilo de un romance de ciego:

Vamos a cantar, señores, / estos cuplés de la niña / que cautivaron los moros / en los riscos de Melilla.

Y la segunda parte se correspondía con el tema propiamente dicho, que no era otro que la vulgata o versión más difundida de aquel romance, la que empieza con los siguientes versos:

Y el día de los torneos / pasé por la morería y vi una mora lavando / al pie de una fuentecilla.

(Díaz 1983, 69)

Cuando la informante empezaba a cantar esta parte dijo en voz alta, pero como para sí misma o, mejor, en complicidad con quienes escuchábamos: - - Y ahora empieza... Ella contaba con que su audiencia iba a reconocer esta narración y su música, luego era consciente del exordio introducido por algún ciego coplero para actualizar el asunto. La primera parte 
funcionaba como un "recuerdo" bastante reciente en el tiempo de lo que podía ocurrir en Melilla a cualquier soldado allí destinado, que además los oyentes habrían identificado en su momento con cualquier joven del pueblo. La segunda venía de un tiempo remoto y, sin embargo, era ya más reconocible - e incluso más actual- cuando la informante nos la cantó que la otra. No había pasado de moda. Era memoria. Una, podía fecharse con cierta exactitud y la informante recordaba bastante bien las circunstancias en que la aprendió. La otra, no podía recordar cuándo había empezado a conocerla, ni si la escuchó a su madre o abuela, o a cualquier persona del pueblo: la sabía "de siempre".

La misma informante, Flor Frías, de 80 años cuando me recitó y cantó el romance — hace ya un par de décadas- en El Burgo de Osma (Soria), también me transmitió otro relato muy difundido, el de "La boda estorbada" o "La condesita", igualmente con una introducción "de época". El mismo tipo de versión actualizada sobre el viejo tema lo volví a escuchar en una grabación que me cedieron desde otra localidad soriana, Duruelo:

Dale, dale maquinista / dale, dale fuego al tren que vienen los reservistas / no se pueden detener.

En este caso, el exordio aludía a la guerra de Cuba:

Que van a la guerra de Cuba / y allí todos morirán.

(Díaz 1987, 194)

Cuando la informante de El Burgo comenzó con los archisabidos versos de "La condesita" de nuevo nos indicó: - Y ahora es cuando viene... Prosiguiendo, después, con el romance en sí: 
Si a los siete años no vuelvo/ te puedes, niña, casar.

En este caso entonó ambas partes con la misma melodía - aquella con la que había aprendido el romance-. A este asunto de "La condesita" volveremos luego por otro motivo porque el final de éste podría tener, en mi opinión, algo que ver con los caminos de la memoria a los que me he referido, ya que alude explícitamente a la recuperación o "despertar" de ésta.

4. Historia y literatura en la recuperación del pasado: la memoria como curación

La memoria en la oralidad — como hemos visto- es continua: se está constantemente actualizando y nutriendo con nuevos recuerdos. Podemos, pues, suponer que es - justamente- esa capacidad de perpetuar y adquirir conocimientos desde una interacción oral lo que reivindicaba Sócrates en su aparente crítica de la escritura. Pues ésta "reflejaría", pero no "sería" ese saber que se mantiene y surge de la intercomunicación entre el que dice y escucha: del diálogo. El modelo platónico supone, de otro lado, que las imágenes que creemos recordar $-\mathrm{o}$ con las que vemos el mundo- son reflejo de ese otro mundo de las ideas previo y del que procederían nuestros verdaderos conocimientos. Cabe pensar que por la palabra y no por la escritura, su reflejo o recordatorio, seguimos ligados a ese mundo precedente, lo hacemos próximo. En realidad, ese mundo de las ideas podría traducirse - también - como la estructura universal de la mente humana, en virtud de la cual concebimos y vemos (o nombramos) las cosas. La escritura —entonces - sólo sería un recordatorio de ello, no la memoria misma. Ni siquiera un "fármaco de la memoria", tal como revelaba el rey de la dudosa leyenda egipcia. El fármaco, suponiendo que la memoria verdaderamente lo sea, puede —además - ser curación o veneno e 
incluso veneno que cura. Pero resulta interesante la noción defendida por Freud — siglos después — de que el conocimiento, la consciencia de lo que no éramos conscientes, tiene — por sí- fines benéficos, terapéuticos. La conviccción de que la palabra o verbalización del problema oculto cura.

Ello nos lleva a la pregunta fundamental: ¿por qué se recuerdan u olvidan las cosas? Y, más allá, ¿qué impresiones valdría la pena recordar o sería conveniente que no se olvidaran? La literatura - oral o escrita - sirve para recordar sensaciones, para eternizarlas, e incluso hace memorable lo que no ha sucedido. Constituye un instrumento principal de la memoria humana, lo que es como decir que nos proporciona un recurso probablemente imprescindible para ser hombres. La primera literatura fueron los mitos, que no en vano ni por casualidad nos hablan en todas las culturas de los orígenes de los dioses y los hombres.

Ginzburg se refiere a cómo esa memoria que parece dar un sentido diferente a la historia mediante su recuperación consciente ha sido empleada en distintos casos con el propósito de devolver la salud al cuerpo social, la dignidad de los países: ha permitido que naciones enteras pudieran volver a mirarse y reconocerse. Y cita este autor los ejemplos de los juicios sobre el régimen de Vichy en Francia y la comisión investigadora del apartheid en Sudáfrica. Dice, así, Ginzburg a propósito de ellos que, hoy, parece querer tenderse "un puente entre la memoria y la historia a fin de fomentar las condiciones no sólo, a nivel general, de una 'memoria feliz', sino también de un 'olvido feliz"” (Ginzburg 2004, 38).

Probablemente las actividades de recuperación de la memoria histórica en España persiguen un fin parecido ante un problema nacional como fue el hecho de que se pasara de puntillas y sin dictar justicia sobre los desmanes ocurridos durante y después de la guerra española. ¿Tiene que hacerse la luz y restablecerse la memoria para que haya justicia? Ésa parece ser la creencia que alienta tras tales iniciativas. La memoria como 
parte imprescindible de la justicia y como su principal auxiliar. Porque ambos - justicia y memoria - estarían de un solo lado, en el mismo bando contra el olvido. O, según declarara Desmond Tutu, el presidente de la Comisión de la Verdad y Reconciliación de Sudáfrica y consigna Ginzburg, "no puede haber curación sin verdad" (Ginzburg 2004, 39). Pero la solución no es tan sencilla como encender una luz sobre el pasado. Y, por ello, se pregunta también Ginzburg, a propósito de la importancia que la política de la memoria ha llegado a cobrar en nuestro mundo globalizado: “¿Cómo debería abordar un país su pasado, especialmente cuando a menudo eso significa abordarlo como una carga?" (Ginzburg 2004, 38).

Hay casos recientes que nos hacen pensar sobre los motivos de la memoria y sobre el por qué se conservan o no determinados testimonios. Primero hay que recordar que, en efecto, presenciamos o creemos presenciar hechos que nos afectan nacional o globalmente: El 11S, el 11M. Un edificio que arde es transmitido en tiempo real por las televisiones y la gente acude allí, aunque esté contraindicado por las autoridades el hacerlo, para participar más directamente del momento: es la Torre Windsor en Madrid, que no ha sufrido ningún atentado, pero remite inmediatamente a la imagen de la Torres Gemelas convertidas ya en icono del tiempo en que vivimos. Y de ahí, seguramente, la fascinación que produce en los televidentes "presenciar" de nuevo el derrumbe de un gran edificio en llamas.

\section{El valor de la memoria: lo que no debe olvidarse}

Tras el $11 \mathrm{M}$ se multiplicaron las expresiones populares en Atocha y en las otras estaciones de donde había partido la gente que encontró la muerte aquel día. Poemas, banderas, altares improvisados llenaron los espacios vacíos convirtiéndolos en san- 
tuario. Tercamente se amontonaron durante días. Y llegó el momento de retirarlos. Lo decretó la autoridad competente en forma de la ministra del ramo: había que "encauzar" esas expresiones y dejar que los servicios de la limpieza actuaran. Se creó, en este sentido, un espacio virtual alternativo donde la gente podía escribir en una pantalla de ordenador sus mensajes: "El espacio de las palabras". No era lo mismo. Aunque el artefacto estuviera allí también —en el nuevo "espacio sagrado" — se perdía en este acto tecnificado "el sentido de lugar" (Appadurai 1996) y probablemente muchas otras cosas. Pero ¿qué pasó con todos los materiales acumulados? Se han guardado.

Desde el Departamento de Antropología de España y América creamos un proyecto que, con el nombre del Archivo del Duelo, pretende conservar y estudiar el vestigio de tales manifestaciones. Pero lo que interesa resaltar ahora es por qué surgió la necesidad de no tirar o arrojar al olvido estos materiales. Nosotros propusimos su preservación y, desde luego, teníamos nuestras razones que los resultados del proyecto irán explicando. Lo que importa es que otra gente directamente afectada por el atentado entendió perfectamente desde el principio esos motivos. Empezando por los directivos de RENFE que hallaron en nuestra propuesta, sin duda, una solución al problema que tenían planteado. Se veían en la obligación de retirar todo "aquello" por razones prácticas, pero habían entendido que podía subyacer algún valor en esos testigos del dolor y que, por lo tanto, no debían desaparecer del todo. Tal parecer no era unánime y también se escucharon voces que, desde la propia empresa, abogaban por un pronto olvido de lo sucedido, ya que perpetuar la memoria del desastre podría perjudicar el negocio. Sin embargo, prevaleció la opinión de quienes habían intuido que "todo eso" era o podía ser importante. Porque lo era para la gente que con todo su afecto lo había depositado. Y probablemente para los que ya no estaban: para los últimos destinatarios de aquellas ofrendas. 
Un lugar de uso público por donde la gente suele pasar sin fijarse mucho, un "no-lugar" se había convertido en "lugar etnográfico" (Augé 1993). Y lo que es más destacable, en lugar sagrado. La gente ahora se paraba a leer los textos, a fotografiar las imágenes, a dejar unas velas, a añadir algo, una humilde ofrenda, a lo que ya estaba allí. En honor de los muertos. Haciéndose uno con ellos. Pues, como ya había figurado en carteles y pancartas durante aquellos días fatídicos, existía un sentimiento generalizado de que "todos íbamos en ese tren". Y, en ese sentido, posiblemente se produjo una refundación de la ciudadanía: la patria de sentirse ciudadanos en común, frente y desde el dolor. En definitiva, no podía desecharse el sentimiento que nos había golpeado pero también unido, que nos había hecho experimentar juntos lo peor, pero también lo mejor: una momentánea solidaridad sin fisuras La Asociación de Afectados por el 11M también lo sintieron así cuando les explicamos el propósito del proyecto.

Estaba claro para ellos y nosotros que lo que se pretendía preservar no era el daño, sino la reacción frente a él. Y fuimos mayoría quienes asumimos que era preferible ser conscientes, guardar memoria de aquel día que pretender —inútilmenteolvidarlo. Por respeto a quienes lo habían padecido, que éramos todos en mayor o menor grado. De nuevo, pues, el valor terapéutico de la memoria. Como Platón, parece que seguimos pensando que lo que se confía a la escritura o a la Historia "está destinado al olvido, porque nuestra memoria — si es recogida por signos ajenos a nosotros- se atrofia" (Ginzburg 2004, 33). Habría que mantener viva la memoria de otra forma: favorecer y garantizar su continuidad. Consignar meramente los hechos, sus datos fríos, nos separa de lo ocurrido. Nos aleja, en cierto modo, de lo que se sintió. Y esta vez no se quería olvidar más. Se trataba de lograr que el hecho se perpetuara de otra manera, mediante el mito conservado de boca en boca o a través del rito que pautada y cíclicamente sirve para evocarlo. Porque el mito, 
más que la escritura, nos preservaría — según los antiguosdel olvido:

Platón alude a la fuerza del olvido en su Timeo (22 A-C), donde menciona las tradiciones olvidadas sobre el pasado griego que se habían conservado en Egipto. Pero no creía que escribir pudiera ser útil en casos así. Al contrario, como sabemos por el mito seudoegipcio narrado al final del Fedro, los que confiamos en la escritura estamos destinados al olvido, porque nuestra memoria se atrofia. (Ginzburg 2004, 33)

Sigue diciendo Ginzburg —en esta misma línea—:

Podría pensarse que estos debates no nos afectan. Hoy en día muy poca gente (si es que queda alguien) suscribe la doctrina que fundamenta el ataque de Platón a la palabra escrita, por no decir que el mundo en que vivimos es muy diferente al de Platón. Pero los argumentos de Platón todavía resuenan en nuestro interior. (Ginzburg 2004, 33)

Y — como ya vimos - esos argumentos reaparecen también en los conceptos sobre el proceso de recordar que yacen escondidos en nuestro lenguaje. Esa clase de memoria continuada, desde antes y más allá de lo escrito, sería como un anillo que nos une sutilmente con el pasado: o, mejor, que hace constantemente presente ese pasado. Ginzburg explica que "tanto Platón como Aristóteles utilizaron el anillo sellado como metáfora, relacionando la memoria con una experiencia social generalizada que abría un espacio de limitaciones y posibilidades cognitivas" (Ginzburg 2004, 35).

\section{Oralidad y textualidad en la construcción social de la memoria}

En el romance al que antes me he referido - una balada que se cantó en varios países europeos-, conocido como "La boda 
estorbada" o "La condesita", uno de los personajes protagonistas parece haber perdido la memoria. Cuando se va a esa guerra aludida en los versos antes transcritos, el conde (Sol o Flores según las versiones) se separa de su mujer diciéndole que si "a los siete años no vuelve" ella podrá casarse. Pero la condesita, cuando pasa ese tiempo, en vez de olvidar al conde elige la memoria y se marcha a buscarlo. Cuando finalmente lo encuentra, éste está distraído o decididamente amnésico y dispuesto a casarse con otra mujer. La condesa consigue que el conde la reconozca como "su mujer natural", enseñándole el vestido de casamiento que lleva bajo su ropa de romera con el que ha ido a buscarle y por la referencia al anillo que el conde lleva.

Yo pido ese anillo de oro / que en tu dedo chico está.

(Díaz 1983, 60)

Es el anillo de las viejas canciones de gesta como la de Horn y Rimel (Galmés 1971, 123). El anillo que enlazado con otro hace cadena y une los tiempos, "ese objeto desconcertante colocado en la intersección entre imágenes y escritura, entre presencia y ausencia" (Ginzburg 2004, 35). El anillo que impide la ruptura con lo que fuimos, la quiebra del tiempo. El anillo que asegura la permanencia de los sentimientos, de las sensaciones, que sirve para imprimir una imagen en la arcilla o la cera. Si nosotros hemos olvidado lo que éramos, él nos recordará lo que fuimos. Es lo oral y lo escrito - en esa capacidad de los anillos para imprimir letras sobre ciertas superficies-, el nexo que enlaza lo uno y lo otro. Es el relato, es la literatura. Porque es la manera de sentir, aquello que hemos sentido en común con alguien lo que nos da la medida de lo que somos. Las sensaciones, el sentimiento, más que lo que pensamos, la manera en que hemos sido afectados por algo nos hace semejantes a unos y otros. Nos hace humanos. 
La memoria es lo que uno cuenta a otro —o a sí mismo-, lo contado desde otro tiempo en el presente. Porque, al final, es una cuestión de tiempo, de cómo concebimos el tiempo, de lo que estamos tratando. Gérard Namer establece, de la mano de Halwachs y respecto al dualismo de la memoria (en lógica y vivida o conceptual e intuitiva) de Bergson, que hay "una sola memoria cuyos contextos colectivos son nociones que pueden ir del pensamiento a la imagen o de la imagen al pensamiento". Lo que quizá, más que negar, aclare los viejos conceptos —aún vivos en nuestras lenguas-, de memoria y recuerdo. Pues, según puntualiza Namer, "el tiempo es por lo tanto, bajo diversas formas, de larga duración y virtual en la escritura, y es a la vez transhistórico por el concepto e histórico a través de lo vivido" (Namer 2004, 93).

La memoria a que se referían Platón y Sócrates sería la "transhistórica" o la que funciona como tal, y tiene las características de ser oral y dialéctica, colectiva, continuada, abierta, porque se basa en que alguien cuenta a alguien; mientras que el recuerdo — ligado a la escritura por aquéllos_-, sería, sin embargo, aislado, cerrado en sí mismo, individual - aunque transcienda de una individualidad, la del autor, al lector-, "histórico", y por ello ligado o limitado a una época concreta. Una de estas formas de memoria, la del recuerdo, sería un hecho, la otra una capacidad, la de recordar desde la interrelación. La escritura nos ofrece y conserva una serie de recuerdos, de fragmentos de memoria, lo que conduce a la ruptura del tiempo, si bien lo podamos recuperar después y hacer presente. $\mathrm{O}$ creer que lo hacemos. Pero hemos perdido el sentido del camino que conducía a él, la percepción del sonido aunque nos llegue aún su eco y lo más importante: no sabemos ya cómo y por dónde podemos ir al encuentro de ese tiempo olvidado. Han quedado borrados los pasos intermedios que son los que el historiador o el crítico intentan reconstruir averiguando más sobre el contexto perdido, la biografía del autor, su circunstancia histórica. La 
quiebra de la memoria nos ha conducido al fragmentarismo del mundo. Es un puzzle cuyas piezas hay que recombinar para que la imagen recupere su forma. La memoria de la voz, de las voces nunca del todo extinguidas, es — de otra parteel mito que se continúa a través de nosotros.

Pero hay un punto en que cierta comunicación escrita, como - por ejemplo — la de internet, se acerca más a lo primero (la memoria) que a lo segundo (el recuerdo) en su propio carácter aparentemente efímero que constituye — no obstanteel sello de su otra continuidad. Tal comunicación internáutica dura poco aparentemente, se borra, queda engullida en una cadena de comunicaciones: el anillo que enlaza los tiempos. Y, sin embargo, como los viejos mitos y leyendas de que - a menudo - se nutre, jamás desaparece del todo. Ahí, a pesar de lo que dice Ginzburg, creo que puede pensarse en que la diferencia de grado pasa a ser también una diferencia de tipo. Las leyendas y rumores populares que circulan a través de internet son tanto oralidad como escritura, pues - por lo generalparticipan de ambas vertientes de transmisión.

Retomemos, de otro lado, y en orden a aclarar algo más los posibles tipos de memoria, la comparación que Ginzburg hacía entre las dicotomías memoria/recuerdo y la información/ recuperación de una base de datos. Aparte de "lo tentador" que - según el propio Ginzburg — resultaría comparar ambas parejas de oposiciones (Ginzburg 2004, 33), cabe encontrar en tal paralelismo una pertinencia que - hasta ahora - no hemos llegado, quizá, a destacar lo suficiente. La inteligencia de los ordenadores es artificial, pero está construida sobre el modelo humano. El cómo funciona puede servir para saber cómo funciona la nuestra: de qué procesos consta. El modelo puede servir, pues, para que entendamos mejor el funcionamiento y estructura del original.

Cuando, por ejemplo, tras una avería o incluso un siniestro la información de un ordenador no parece recuperable, lo que 
ocurre es que no tenemos - temporalmente- acceso a ella, pero esto no significa que los datos hayan desaparecido en realidad del disco duro: la memoria sigue ahí. El usuario pierde la posibilidad de acceso a una información que no se ha perdido del todo. Los expertos en recuperar la información de ordenadores siniestrados tras un incendio lo explican muy claramente: hay que poner en marcha los dispositivos para acceder a los datos, algo que en un usuario corriente no sabe normalmente hacer. El experto sí. Los datos, los recuerdos desaparecen, voluntaria o involuntariamente, en esa selección o accidente que es el olvido. Un fuerte shock nos hace olvidarlos y recuperarlos nos ayudaría a superar el shock en sí, según Freud defendía y Benjamin recuerda:

Cuanto más habitualmente se registra (el shock) en la consciencia, tanto menos habrá que contar con su repercusión traumática. La teoría psicoanalítica intenta entender la naturaleza del shock traumático 'por las brecha que se abren en la defensa frente a los estímulos'. En su opinión el terror tiene 'su significación' en una 'falta de disposición para el miedo'. (Benjamin 1993, 130)

Todo esto iluminaría — también — algunos de los casos que hemos recordado como el de la memoria que se quiere reconstruir tras los shocks colectivos. Si la memoria no se pierde del todo sería más fácil recuperarnos del shock: quizá por eso la gente intuye que no debe arrumbarse en el olvido lo que surgió a partir de él (11M). Que no debe perderse la memoria de los hechos más terribles aunque sea dolorosa (la ocupación nazi, el apartheid). Recordarlos ya sería hacer justicia de alguna manera:

Las duras realidades del pasado — dirá el arzobispo Desmond Tutu - tenían que conocerse a fin de conseguir la 'unidad nacional a través de la verdad y la reconciliación'. (Ginzburg 2004, 39) 
Lo oral, que en absoluto ha desaparecido en nuestro mundo, sino que se ha mantenido incluso contaminando medios como internet, garantiza la continuidad de una identidad, la de lo vivido, sin lapsus, sin quiebras, sin que se fragmente la unidad de lo que fuimos y lo que somos. La escritura, y la historia desde ella - pues tradicionalmente se ha basado en los testimonios escritos-, realizan o pretenden realizar la misma función, pero mucho más fragmentariamente. La memoria sería la actualización constante del recuerdo y — en cierto modo- de la historia. La historia comienza donde la memoria termina. Si hay memoria parecen decirnos e ilustrarnos todos estos casos citados, la historia no es aún necesaria. Vendrá después. En ese sentido la memoria es transhistórica, porque actualiza y hace presente el pasado como lo oral actualiza el mensaje: "La tradición como todo lo que vive — decía Menéndez Pidal refiriéndose a la pervivencia de la literatura oral- se transforma de continuo, vivir es variar" (Menéndez Pidal 1969, 40). La frase resultaría aún más acertada si sustituyéramos "tradición" por "memoria"; sustitución que en absoluto traiciona el sentido de las palabras de Menéndez Pidal, pues reiteradamente insistiría en que, a diferencia de lo que había ocurrido en otros países donde "el olvido (de los poemas épicos) fue completo. En España el pueblo recordó persistentemente muchos de sus fragmentos", lo que en su opinión daría origen al romancero $(1969,11)$.

7. La otra historia: la memoria colectiva como corriente permanente de conocimiento e identificación

La actualización del tiempo niega el tiempo. Impide ese olvido. Vuelve eternas las vivencias. Sócrates está tan vivo en nosotros como Platón y Aristóteles — aunque jamás escribiera nadapor lo que fue capaz de transmitir a sus discípulos: no unos pensamientos, no un sistema, sino una forma de pensar. No sólo se 
ocupaba de las cosas de la moral o humanas más que de las ciencias de la naturaleza como señalaran Jenofonte o Aristóteles. Nos enseñaba que todo lo que sabemos lo aprendemos desde nosotros. Y mostraba también Sócrates la importancia de lo contado de uno a otro y por ambos en una cadena, la del anillo, inacabable: lo que enlaza a todos los humanos, la universalidad de las sensaciones, de las impresiones de las imágenes y la reflexión sobre ellas. Si nuestra continuidad con Sócrates viniera únicamente de lo que sabemos de él por Platón, por lo que éste dejó escrito, quizá no fuera suficiente para sentirle —en muchos aspectos - tan próximo. Hay otra continuidad que es la de la cultura, en su sentido de cultura popular, que en realidad es la cultura en sí, sin necesidad de adjetivos, pues éstos se los ponemos para diferenciarla de la otra, la escrita, la culta, que es la que supone una metacultura, un salto con separaciones y recuperaciones en la historia de la humanidad. Eso que llamamos cultura popular es la cultura que aprendemos casi sin saberlo. Y aquí cobra todo su sentido el párrafo antes trascrito de Freud, pero dándole —en parte- la vuelta al argumento. No es esa cultura de las leyendas y costumbres menos cultura o menos fiable desde el punto de vista de la continuidad humana que la otra, la de la Historia, los libros y los documentos, sino - quizá- todo lo contrario. Es esa continuidad la que nos permite creer que podemos sentir y hasta pensar como los que nos precedieron, más que el saber por escrito de sus palabras o sus hechos. Más que el que recuperamos sus enseñanzas a través de la escritura o cualquier otro medio técnico que sólo cumple la apariencia de reanudar los tiempos y las experiencias separadas.

El éxito de géneros literarios como las memorias o las novelas históricas en la actualidad posiblemente nos esté indicando - entre otras cosas - la necesidad de conectar con el pasado, de reanudarnos con una experiencia rota. Y toleramos como verosímil, por ejemplo, reproducir lo que dijeron o pensaron quienes vivieron en una época remota — según unas convenciones 
narrativas que nos parecen plausibles - pues asumimos que es factible superar, desde lo humano, la distancia que nos separa de ellos (aun sabiendo que los personajes que allí aparecen no hablaron exactamente así). Lo que es extensible a la historia en sus primeros balbuceos, ya que Tito Livio ponía en boca de los personajes de siglos anteriores — que no había podido conocer, por lo tanto- largos discursos reconstruidos por él. Y seguramente el propio Platón también pusiera en labios de Sócrates - aunque fueran contemporáneos- palabras que éste nunca pronunció, puesto que escribió lo que decía algún tiempo después de que Sócrates hubiera muerto.

El texto es siempre un vestigio separado de quien fue y de lo que esa persona que fue vivió. Se puede, eso sí, reflejar mejor o peor el espíritu de lo que decía o el sentido de sus acciones. La continuidad de una lengua, de unas costumbres, de unas creencias, de una tradición, a las que apelaba Freud, es lo que nos une al pasado y permite que lo reconstruyamos en la convicción de que no traicionamos lo que también fueron y sintieron nuestros antepasados. La cultura es nuestra memoria social. Puede parecer que reconstruir lo que sintió Sócrates ante una sentencia injusta — que no obstante pensaba debía cumplirse — o lo que sintieron los paganos de finales de la edad antigua antes de que su mundo se desmoronara, no resultara ni siquiera susceptible de ser evocado por nosotros. Y probablemente no lo fuera si hacemos del juicio de Sócrates una película americana de juicios o del fin de aquel mundo otra de indios y vaqueros. Pero basta leer lo que ya en el siglo vi reprochaba Martín de Braga a los rústicos en su De Correctione Rusticorum - traducido habitualmente como Sermón contra las supersticiones de los rústi$\cos$ (1981) — , para darnos cuenta de que las costumbres paganas que les recrimina en gran parte las seguimos practicando nosotros:... No somos los mismos, pero no estamos tan lejos de ellos tampoco. Si lo estuviéramos no sería posible comprender otras culturas de otra época o espacio y, sin embargo, creo que 
lo es, que la traducción es posible. Lo que quizá no lo resulte sea una reconstrucción cabal de época. Sí una empatía con sentimientos o sensaciones de esos hombres remotos, porque una corriente subterránea de tradiciones nos enlazan mutuamente; en especial a aquellos con los que no dejamos de compartir una cultura cuyos orígenes están en su lenguaje y pensamiento.

El texto constituye un recuerdo aislado, pues, como sigue diciendo Rivas en el fragmento que encabeza este trabajo "nosotros no escogemos los recuerdos, ellos viven su propia vida" (Rivas 1994, 50). La memoria oral nos liga directamente con lo anterior. La inteligencia artificial de los ordenadores nos aclara e ilustra —en efecto- cómo funciona la nuestra. No es su metáfora, sino su copia fiel. Los recuerdos son los datos aislados que la memoria guarda y los programas la facultad de la memoria de recuperarlos, lo que activa la memoria: eso que llamamos recordar. El término memoria es, pues, utilizado por nosotros tanto para designar lo que se guarda como para referirnos a la facultad de recordar que sería el programa introducido en los ordenadores. Los términos utilizados al respecto - como vemos - siguen siendo tan elásticos pero indicativos como los que utilizaba Platón. Si no tenemos el programa con que descifrar un código lingüístico no entenderemos nada: las embolalias de los niños imitan el lenguaje pero no son el lenguaje. Los recuerdos y los sueños a veces imitan a lo vivido, pero su código está incompleto sin la memoria.

Hay, sin embargo, otros aspectos que no afectan a los ordenadores y sí a los humanos. ¿Por qué entendemos que un sueño o un recuerdo son o pueden ser importantes para nosotros y los reconstruimos - como enseñaba Freud en sus ejemplos del psicoanálisis del arte- o los recordamos a nuestro pesar? ¿Por qué creemos que un hecho merece ser recordado y ponemos en marcha los mecanismos para acceder a él? En el sueño - muchas veces - seguimos recordando nada más despertar palabras, frases o imágenes sueltas, a menudo inconexas en apa- 
riencia. E incluso en ocasiones de modo que la banda de las imágenes y la de las frases parecen no estar sincronizadas como cuando vemos una película en que sonido e imágenes no se corresponden por estar aquélla defectuosa. Pueden ser también secuencias de imágenes o frases que — dentro de sí mismas — tienen una lógica, pero una lógica que aún no comprendemos. No sabemos a qué vienen ni por qué frases e imágenes son percibidas de manera disociada como si la máquina de la memoria en ese momento no funcionara bien. La sintaxis de lo uno y lo otro puede ser sin embargo correcta. Freud descubrió que puede haber una lógica en esos sueños y esos recuerdos sobre los que es posible indagar desde otra perspectiva, introduciendo otro programa en el presente que nos sirva para recuperar su sentido.

Tanto en inglés como en español las distinciones no están muy claras — como ya vimos-, desde un punto de vista semántico, cuando nos referimos a las capacidades, funciones y procesos envueltos dentro del vocablo memoria. En ambas lenguas, memoria (memory), recuerdo (remembrance) y el acto de recordar (remember) cuentan con palabras distintas para señalar cada concepto, pero también pueden coincidir o usarse el mismo término para unas y otras cosas. En las dos lenguas recordar y recuerdo tienen además la misma raíz o lexema. Recapitulemos sobre esta maraña de términos y conceptos y sus posibles características tal y como hemos venido exponiéndolas hasta ahora:

\begin{tabular}{|c|c|c|}
\hline $\begin{array}{c}\text { MEMORIA } \\
\text { (y la propia información } \\
\text { archivada) }\end{array}$ & $\begin{array}{c}\text { RECORDAR } \\
\text { función-proceso } \\
\text { (<e modo continuado } \\
\text { o interrumpido>) }\end{array}$ & datos \\
\hline memoria transhistórica & <estímulo oral o escrito> & $\begin{array}{c}\text { memoria histórica archivos } \\
\text { separados unos de otros }\end{array}$ \\
\hline $\begin{array}{c}\text { transmisión oral } \\
\text { carácter colectivo }\end{array}$ & $\begin{array}{c}\text { transmisión escrita y oral } \\
\text { carácter individual }\end{array}$ \\
\hline $\begin{array}{c}\text { (información completa) } \\
\text { cambiante }\end{array}$ & & $\begin{array}{c}\text { (información fragmentaria) } \\
\text { fijada }\end{array}$ \\
\hline
\end{tabular}


La memoria es facultad y depósito de la información al tiempo. Transhistórica si el proceso de recordar actúa a través de una cultura no almacenada por caracteres ajenos a lo humano, mediante la palabra o, en última instancia, la voz. Los recuerdos entonces están incluidos en ella, no tienen vida separada. La pervivencia del mito, del relato de nuestras vidas y experiencias y de los que vivieron antes que nosotros sería lo que llamamos memoria, la suma de lo que somos incluso antes de que tuviéramos un yo personalizado. No hablamos de un "inconsciente colectivo", sino de un conocimiento del que podemos no ser del todo conscientes, como no lo somos del aprendizaje de hablar o andar, pero que —en su momentoaprendimos. Nos une a otros hombres y a todos los hombres. Es la totalidad y unicidad de lo humano.

La mentira o al menos la impostura del folclorismo estriba en confundir el recuerdo con la nostalgia. La cadena de la memoria estaba rota o a punto de romperse cuando ese interés por el folclore surge en la segunda mitad del XIX. Y su advenimiento no evitó la ruptura del tiempo transhistórico. Es más, surge en parte por la nueva conciencia de esa pérdida a la que se considera irreparable. Ese primer folclorismo sirve para presentar a un pueblo remedo de sí mismo, al pueblo auto-representándose, disfrazado convenientemente de manera típica y haciendo lo que se espera de él: bailar, cantar, tocar instrumentos arcaicos. En España hay un hecho que marca el inicio de este proceso de manera espectacular: los primeros "coros y danzas" que, en 1878, son llevados por los poderes que impulsan la Restauración monárquica a hacer de comparsas en la boda de Alfonso XII con sus correspondientes trajes regionales. Se trataba de demostrar que el pueblo apoyaba a la monarquía restaurada, que sentía con ella y se regocijaba con la alegría del monarca por su boda. La escenificación de ese pueblo recreado con vestimenta típica plasma visualmente esa intención y es así recogido en fotos de la época (Fototeca Nacional, 
Archivo Ruiz Vernacci). La gente que los veía pedía a los figurantes que cantaran o danzaran, que les hicieran —en definitiva - algo "tradicional", pero también "buscaban con ansia las comparsas de sus pueblos respectivos" para reconocerse (La Época 1878). Desde entonces, el pueblo no dejará de aparecer mil veces en nuestro país representado y manipulado por personajes que pretenden rescatar lo tradicional e interpretarlo "auténticamente" frente a un público.

En paralelo a este proceso, las denominaciones con los que los recuperadores de un pretendido pasado intemporal aluden al pueblo se irán volviendo cada vez más restrictivas: la cultura popular será identificada con el folclore y luego con la cultura tradicional, términos que sirven para separar cada vez más a la cultura del pueblo y a ese mismo pueblo de la nuestra: el concepto de pueblo quedará ligado a campesinos de zonas deprimidas, a atrasados nativos que aún recuerdan algo del ayer pero no saben por qué saben. Lo que es una prueba de que esa sabiduría o "filosofía vulgar" que compartían todos y a la que se referían por ello con tales términos los humanistas del Renacimiento (Mal Lara 1568) ha pasado a ser una rareza de un pueblo exhibido en las ferias por su singularidad, por su tipismo.

Parecería, así, que la memoria continua y transhistórica de la colectividad se hubiera roto definitivamente. Pero no. Se sigue transmitiendo en lo que otros nos cuentan cuando apenas balbuceamos el lenguaje. No parece extraño, no parece típico y sin embargo está ahí. En el territorio de la infancia. Un paisaje en que hubiéramos podido "oír el viento y las campanas, si hubiésemos estado más atentos" (Benjamin 1982, 21). Y lo estábamos, en cierto modo, nuestra memoria registró el sonido de aquel viento, de las campanas y de los cuentos. Aprender un lenguaje es aprender a pensar y ver el mundo de una determinada manera. De esas primeras experiencias, en realidad de cualquier experiencia susceptible de ser formulada en 
palabras, nacen todas las historias. La memoria seguirá ahí aunque no siempre sepamos o acertemos a acceder a ella y a su valor de posible bálsamo. Es, sí, un pharmakon que puede actuar como medicina o veneno (Ginzburg 2004, 40), pero que - en todo caso- constituye la raíz de la que se nutre el árbol de lo humano. Los testigos de las atrocidades de la guerra civil a menudo dicen que "perdonan, pero no olvidan", que aquello que vivieron estaba "enterrado, pero no olvidado". Y las víctimas del 11M que lo que vieron "ya nunca se va" (en el programa de Espejo Público emitido por Antena 3 el 6 de marzo de 2004).

Dice Benjamin en un texto del libro Infancia en Berlín donde recoge minuciosamente algunos recuerdos de su niñez que él, a su manera, hará reveladores y premonitorios como un nuevo Leonardo:

El recuerdo de la cena y de los zarzales del frambueso me agradaban tanto más por cuanto el cuerpo se sentía por encima de la necesidad de comer alguna cosa. En cambio le apetecían las historias. Las fuertes corrientes que las llenaban le atravesaban y arrastraban el mal como un objeto flotante. El dolor era un dique que sólo al principio se resistía al relato. Más tarde, cuando éste se hubiera robustecido, quedaría minado y arrastrado al pozo del olvido. Las caricias iban haciendo el cauce de esta corriente. Me agradaba pues la mano de mi madre que empezaba a hilar las historias que pronto saldrían en abundancia de sus labios. Con ellas salió a la luz lo poco que llegué a saber de mis antepasados. (Benjamin 1982, 81-82)

La memoria es lo que nos pasa e incluso lo que no nos pasa. Determinará incluso en gran medida lo que nos vaya a ocurrir. Los episodios de nuestra vida son la apariencia visible, las fachadas de las casas que vemos al pasar por una calle, pero la memoria son los entramados que las sostienen, su estructura, el revés de la trama; un conocimiento que, en oca- 
siones, parece invisible, pero permanece allí en la sombra. La escritura sería la huella de la pisada en la nieve, el vestigio de la palabra — siempre haciéndose y cambiando de lugar-y la memoria la forma de ésta, la planta que la hizo posible. La

misma forma que quedará tras nuestros pasos en el níveo suelo que aún está por venir.

\section{REFERENCIAS}

Appadurai, Arjun, 1996. Modernity at Large. Cultural Dimensions of Globalization, Minneapolis-London, University of Minnesota Press.

Augé, Marc, 1993. Los "no-lugares". Espacios del anonimato. Una antropología de la sobremodernidad, Barcelona, Muchnik Editores.

Benjamin, Walter, 1982. Infancia en Berlín hacia 1900, Madrid, Alfaguara.

—, 1993. "Poesía y capitalismo" en Iluminaciones II, Madrid, Taurus.

Braga, Martin de, 1981. Sermón contra las supersticiones rurales, texto revisado y traducción de Rosario Jove Clos, Barcelona, Ediciones El Albir.

Díaz G. Viana, Luis, 1983. Romancero tradicional soriano, vol. I, Soria, Diputación Provincial.

—, 1987. Palabras para vender y cantar, Valladolid, Ámbito Ediciones.

—, 2001. Palabras para el pueblo. La colección de pliegos del CSIC: Fondos de la Imprenta Hernando, vol. II, Madrid, CSIC.

—, 2003. El regreso de los lobos. La respuesta de las culturas populares a la era de la globalización, Madrid, CSIC.

Freud, Sigmund, 1973. Psicoanálisis del arte, Madrid, Alianza Editorial.

Galmés, Álvaro (et al.), 1971. El romancero oral, Madrid, Seminario Menéndez Pidal.

GinZBurg, Carlo, 2004. "Memoria y globalización", Historia, Antropología y fuentes orales 32, 29-40. 
Gómez Soto, Ignacio, 1999. Mito y realidad de la lectura. Los hábitos lectores en la España actual, Madrid, Ediciones Endimión.

Goody, Jack, 1985. La domesticación del pensamiento salvaje, Madrid, Akal.

Gran Diccionario General de la Lengua Española, 1994. Revisión de Manuel Alvar Ezquerra, Barcelona, Vox.

La Época, 1878. Fototeca Nacional, Archivo Ruiz Vernacci, Madrid, Instituto del Patrimonio Histórico.

LoRD, Albert, 1960. The Singer of Tales, Cambridge, MA, Harvard University Press.

Mal Lara, Juan de, 1930 [1568]. La Philosophia vulgar, Sevilla, ed, facsímil de la Hispanic Society of America, New York.

MenÉndez Pidal, Ramón, 1969 [1938]. Flor nueva de romances viejos, Madrid, Espasa-Calpe.

—, 1973. Estudios sobre el romancero, Madrid, Espasa-Calpe.

Namer, Gerard, 2004. "La sociología del tiempo", Historia, Antropología y fuentes orales 32, 91-97.

Platón, 2000. Fedro, trad. Emilio Lledó, Madrid, Siglo XXI.

ReDFIELD, Robert, 1960. "The Social Organization of Tradition", en The Little Community. Peasant Society and Culture, Chicago, The University Press, pp. 40-59.

Rivas, Manuel, 1994. En salvaje compañía, Madrid, Alfaguara.

Zumthor, Paul, 1983. Introduction à la poésie orale, París, Éditions du Seuil. 